- 0.125 millisieverts per hour; $\mathrm{mSv}^{-1}$ ) were restricted to a narrow band within $40 \mathrm{~km}$ of the plant, stretching to the northwest (see 'Fukushima's fallout'). No values anywhere exceeded $0.3 \mathrm{mSv} \mathrm{h}^{-1}$, a dose likely to cause adverse health effects in anyone continually exposed for a few months. Still, doses at some sites over the course of a year would top $1,000 \mathrm{mSv}$, enough to cause symptoms of radiation sickness, including nausea, hair loss and reduced white-blood-cell counts.

Much of the 20-km evacuation zone around the plant had far lower dose levels, below $0.012 \mathrm{mSvh}^{-1}$. Nevertheless, that corresponds to a potential annual dose of more than $100 \mathrm{mSv}$, more than five times the annual limit permitted for UK nuclear-industry workers. The patchy distribution of fallout reflects the role of wind patterns and rainfall in washing out radioisotopes to the ground. Overall, Smith says he was "relieved" by the data, as they suggest that contamination around Fukushima will be much lower than that seen around Chernobyl.

But some areas of high contamination seem to lie outside the exclusion zone. Soil samples taken on 20 March from a location $40 \mathrm{~km}$ northwest of the plant showed caesium-137 levels of 163,000 becquerels per kilogram $\left(\mathrm{Bq} \mathrm{kg}^{-1}\right)$ and iodine-131 levels of $1,170,000 \mathrm{~Bq} \mathrm{~kg}^{-1}$, according to Japan's science ministry. Acceptable contamination levels for areas used to grow crops are much lower, typically in the range of a few hundred $\mathrm{Bq} \mathrm{kg}^{-1}$. "If there are significant areas of caesium-137 soil concentration of the order of $100,000 \mathrm{~Bq} \mathrm{~kg}^{-1}$, evacuation of these areas could be effectively permanent," says Smith.

Detailed maps of caesium-137 distribution would help to identify hotspots where people need to be evacuated urgently, he adds. An estimated 200,000 people have already been evacuated from Fukushima's 20-km zone, and on $25 \mathrm{March}$, the government encouraged people living in the $10-\mathrm{km}$ radius beyond that to leave voluntarily.

The dispersal of much of the radioactivity over the ocean clearly helped to prevent a worse situation inland, but it is bringing its own problems. Data released last week by Japan's science ministry showed high surface seawater concentrations of 24.9-76.8 becquerels per litre $\left(\mathrm{Bql}^{-1}\right)$ of iodine-131, and 11.2-24.1 $\mathrm{Bql}^{-1}$ of caesium-137 some $30 \mathrm{~km}$ offshore, although these levels seem to be decreasing. By contrast, the IAEA reported this week that radioactivity levels near the plant's discharge pipes were increasing, with $74,000 \mathrm{Bql}^{-1}$ of iodine-131 and

\section{FUKUSHIMA'S FALLOUT}

Data from air and ground monitoring show that highly radioactive fallout is largely localized within a narrow band northwest of the stricken plant.

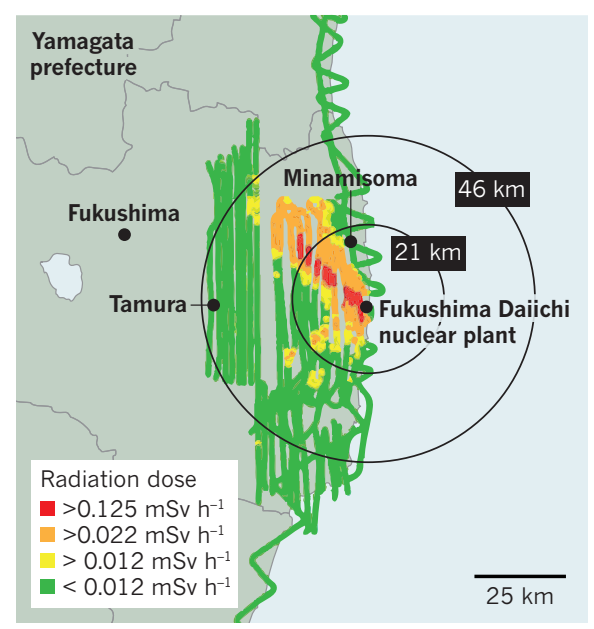

12,000 Bql $\mathrm{B}^{-1}$ of caesium-134 and caesium-137 combined. Recommended maximum coastal discharges from nuclear power plants are typically lower than $4,000 \mathrm{Bql}^{-1}$.

As a result of the nuclear accident, Japan has banned all fishing within $20 \mathrm{~km}$ of the Fukushima plant. Seaweeds and other marine organisms can concentrate radioisotopes from the water, and it will be necessary to monitor their transport through the food chain, says Timothy Mousseau, a radioecologist at the University of South Carolina in Columbia. Smith adds: "There has obviously been significant contamination of the marine system, although I would expect that the enormous dilution of the ocean would significantly limit potential doses and impacts."

On 27 March, a new threat arose from highly radioactive water flooding the basements of Fukushima's reactors, in some areas delivering a potentially lethal dose of $1,000 \mathrm{mSvh}^{-1}$. The water is seeping into piping trenches less than 70 metres from the sea shore, raising the spectre of serious contamination of the sea and groundwater in the area. Yukio Edano, Japan's chief cabinet secretary, has promised a massive effort to prevent that from happening.

As long as the reactors continue to release radioisotopes, the human and environmental toll from the Fukushima power plant can only grow. Once emissions are halted, atmospheric radiation levels will fall quickly, as will ground levels of short-lived isotopes. Iodine-131 is responsible for a large share of the total released radioactivity, for example, and has a half-life of just 8 days. But it may be many weeks, or months, before the power plant is tamed — and years before parts of northern Japan tainted by long-lived radioisotopes are habitable again. -

\title{
Japan faces up to failure of its earthquake preparations
}

\section{Systems for forecasting, early warning and tsunami protection all fell short on 11 March.}

\section{BY DAVID CYRANOSKI IN TOKYO}

$\int \mathrm{n}$ apan has the world's densest seismometer network, the biggest tsunami barriers and the most extensive earthquake early-warning system. Its population is drilled more rigorously than any other on what to do in case of earthquakes and tsunamis.

Yet this month's magnitude- 9 earthquake surprised the country's forecasters. The grossly underestimated tsunami destroyed the world's deepest tsunami barrier and caught people by surprise. And the early-warning system for earthquakes largely failed. What went wrong?

The first problem was the earthquake forecast. Japan's seismic hazard map, the latest version of which was released in March 2009, breaks the offshore area of northeastern Japan into five seismic zones and envisages seven different earthquake scenarios. Each is assigned a probability based on the historical record of earthquakes. The southern Sanriku offshore region, which included the origin of this month's earthquake, was given a $30-40 \%$ chance of rupturing in the next 10 years and a $60-70 \%$ chance in the next 20 years.

As earthquake forecasting goes, these are very high numbers. "That basically means it could happen any day," says Yoshinori Suzuki of the Earthquake Disaster Reduction Research Division within the science ministry, which coordinates the map-making. But the fault was expected to unleash an earthquake of around magnitude 7.7 - about as large as any in the historical record for the area (see Nature 471, $274 ; 2011)$. 


\section{FALSE COMFORT}

A warning system based on initial seismic signals predicted a limited region of intense shaking. The actual shaking was far more severe and widespread.

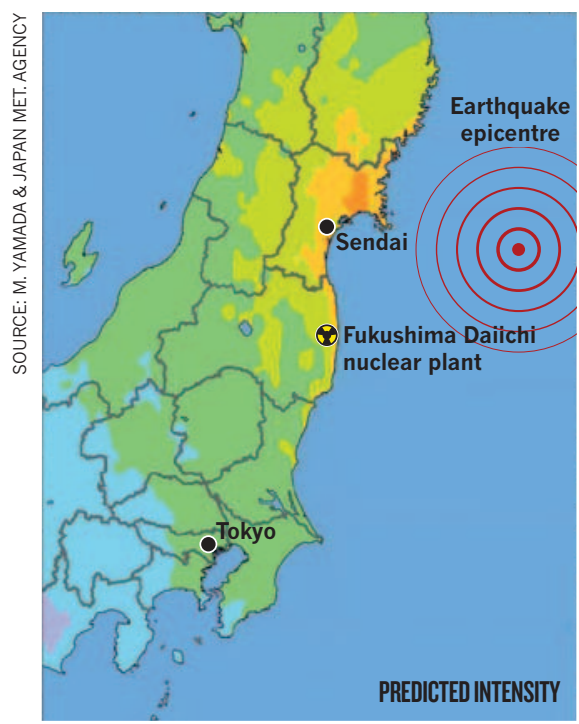

For a separate fault segment offshore from the Fukushima Daiichi nuclear plant, the same forecasting approach postulated only a magnitude- 7.4 earthquake, with a less than $2 \%$ chance of occurring over the next 10 years and less than $10 \%$ over the next 50 years. The government of Fukushima prefecture even refers to the seismic hazard map to boast on its website: "With firm geological foundations and major earthquakes rare, Fukushima is a safe and secure place to do business." What the risk maps didn't allow for, however, was the coupling of segments that allowed the rupture to propagate for some 500 kilometres, unleashing an earthquake of magnitude 9.0 (see 'False comfort').

Japan's earthquake forecasting has had its successes. In 2003, the magnitude-8.3 Tokachioki earthquake occurred right in the middle of a forecasted hotspot. But for the most part, earthquake forecasting, which really took off in Japan in the 1980s and 1990s, has had mixed results, with many devastating quakes hitting outside the expected zones. "We would like to see more hit the marks," says Kyoto University's James Mori.

Despite the surprisingly powerful earthquake, Japan's earthquake-resistant buildings seemed to hold up well. "There was shaking damage but not much considering how strong the earthquake was," says Mori. It was the tsunami that did most of the damage, overwhelming barriers and years of preparation.

The world's deepest tsunami barrier, a 2-kilometre-long edifice at the mouth of Kamaishi Bay on the northeast coast, was completed in 2008 after 30 years, at a cost of more than $¥ 120$ billion (US\$ 1.4 billion). Anchored to the sea floor 63 metres down and rising 8 metres above the water, the 20 -metre-thick breakwater was designed to withstand the impact of a tsunami like the one from the 1896 Sanriku earthquake, which produced waves rising to

nearly 40 metres in some areas.

\section{TSUNAMI RISK UNDERESTIMATED} people," says Fujima. shelter, says Kawata.

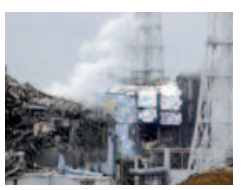

$\rightarrow$ NATURE.COM

For more on the earthquake and nuclear crisis see: go.nature.com/ulsz2n

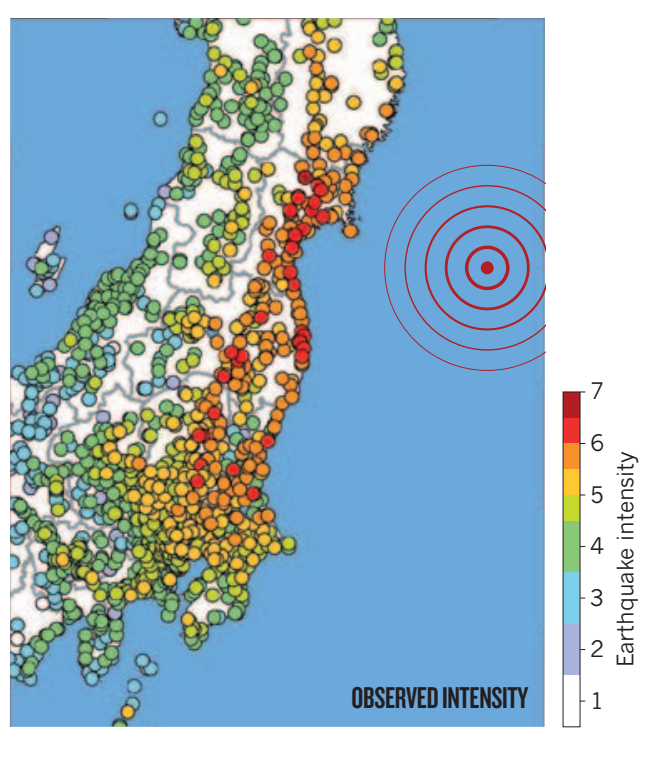

Koji Fujima, a specialist in tsunami wave propagation at the National Defence Academy in Yokosuka, says that this and other structures along the coast gave people a false sense of security. "The region probably gets 2- or 3-metre tsunamis more than once a decade, and people know that the breakwaters will protect them from those," says Fujima. With the hazard map forecasting earthquakes in the magnitude-7.5 range, people would have anticipated a maximum tsunami of $4-5$ metres.

Faith in the barriers seems to have undermined Japan's legendary tsunami-preparedness drills. In northeastern Japan as elsewhere, university professors, research institutes, non-governmental organizations and local civic groups carried out several drills each year to train people in how and where to evacuate. "We were working as hard as we could to educate

Yet people apparently became relaxed about tsunami risks, says Yoshiaki Kawata, a disastermanagement expert at Kansai University. A tsunami originating in Chile last year triggered an evacuation warning to 1.68 million people in northeastern Japan. Only 62,000 sought

"People thought the breakwater was enough," says Fujima. But he adds that "there was no way it could protect them" against the tsunami on 11 March, although it did diminish the wave. Rising an estimated 15-20 metres at sea and 50 metres at some points after hitting the shore, even higher than the 1896 wave, it destroyed the tsunami barriers at Kamaishi and elsewhere and has killed an estimated 20,000 people who had failed to find safe, higher ground. It also swamped emergency generators at the Fukushima Daiichi plant, disabling the cooling system (see page 555 ). Built in the 1960s, the plant was designed to withstand a tsunami of no more than 5.7 metres.

The early-warning system operated by the Japan Meteorological Agency, designed to alert people when an earthquake will create shaking at or above level 5 on Japan's energy intensity scale (severe enough to crack walls), fell short as well. Based on a seismic reading taken a few seconds after an earthquake hits, the system provides up to tens of seconds of warning before the major shaking begins. On 11 March it delivered accurate warnings to areas near the epicentre. But the greater Tokyo region, where many areas experienced level- 6 shaking, received no warning. Bullet trains and nuclear reactors, which have their own warning systems, shut down promptly, as designed.

The problem, according to Kyoto University's Masumi Yamada, was that the system assumes a 'point source' for an earthquake. In this case, the point source led to an estimate of a magnitude-7.2 quake. But as the Sanriku rupture ripped hundreds of kilometres of fault line parallel to the coast, unleashing ever more energy and causing slips of 20 metres or more near the Tokyo region, the system didn't correct itself. The frequent aftershocks also confounded the system, which generated several false alarms and missed large aftershocks.

"The system seems to break down around a magnitude-8 quake," says Yamada. In April, she will start a three-year collaborative project with the Japan Meteorological Agency

"The system
seems to break
down around
amagnitude-8
quake."
to convert the pointsource warning system to a dynamic one that works in two dimensions.

Japan's disaster defences can certainly

be improved, says Fujima, but he thinks that people should recognize that there are limits to what can be done against a "once in a thousand or two thousand years earthquake". Sturdier breakwaters could be built in areas where the tsunamis hit hardest, but they are expensive and could never fully protect against the biggest waves. "People probably should just stop building in the areas where large tsunamis will come," he says.

Kawata, however, puts his faith in better engineering. He agrees that the most effective way to avoid damage is to have people live out of reach of tsunamis. But he envisages houses (and nuclear plants) built on an artificial coastline supported by 10-metre-high concrete pillars. "There are a lot of things we have to do urgently. If we have a vision and we pool our energies, we can do it." 